\title{
Measurement of the effects of a single dose of prazosin on the cerebral blood flow in hypertensive patients
}

\author{
M. D. RutLAND \\ M.Sc., M.R.C.P. \\ C. C. Nimmon \\ B.Sc.
}

T. Y. LEE
Ph.D.

M. GranowsKa

M.Sc. Dr.med.

\author{
K. E. BRITTON \\ M.Sc., M.D., F.R.C.P. \\ Department of Nuclear Medicine and Radio-isotopes, \\ St Bartholomew's Hospital, London ECIA 7 BE
}

\begin{abstract}
Summary
It was considered that the first dose reaction occurring with prazosin may have been due either to hypotension or to a specific reduction in cerebral blood flow. The development of a quantitative non-invasive nuclear medicine technique for cerebral flow has now made it possible to investigate the effects of prazosin on cerebral blood flow in hypertensive patients. This double-blind study showed a significant decrease in BP and a small just significant increase in cerebral blood flow following a single 1-mg dose of prazosin, when compared with a placebo. From these results, it is unlikely that the first dose reactions which occurred with prazosin were due to a specific reduction in cerebral blood flow.
\end{abstract}

\section{Introduction}

Prazosin is an antihypertensive agent which was introduced into clinical use in 1974. Within one year there were reports of patients developing excessive hypotension and associated symptoms shortly after the initial dose (Bendall, Balock and Wilson, 1975; Gabriel, Meek and Ghosh, 1975). The incidence appeared to be dose related and, as a result of these and other studies (Turner, Watson and Brocklehurst, 1977), it is now accepted that most of these 'first dose' effects may be avoided by limiting the initial dose to $0.5 \mathrm{mg}$.

As the mode of action of prazosin is not fully understood, and fainting may result from a marked reduction in cerebral blood flow (CBF), it was felt important to see whether the first dose effects are due to hypotension, or to a specific reduction in CBF. This is especially important because cerebrovascular disease is one of the commonest complications of hypertension. The presence of postural hypotension in patients with 'first dose' effects has already been described (Graham et al., 1976). The development of non-invasive methods of CBF measurement has now made it possible to investigate the effects of prazosin on CBF, and this paper presents the results of such an investigation.

\section{Patients studied}

The study was done on 13 subjects with a spreat of diastolic pressure between 90 and $125 \mathrm{mmHg}$. These included 2 healthy volunteers from the Department of Nuclear Medicine, and 11 patients from the Hypertension Clinic who were included after their informed consent had been obtained. The subjects were aged between 21 and 60 years and had no illness at the time of the study and no signs of cerebrovascular disease. One patient (No. 2) who had had transient cerebral ischaemic attacks but made a complete recovery, was included. Three patients on treatment with $\beta$-blocking agents continued with that therapy, since prazosin is often used in combination with these drugs in clinical practice and there is some anecdotal suggestion that patients taking $\beta$-blockers are more prone to the first dose effect.

\section{Materials and methods}

CBF was measured by the i.v. radioisotope method described and validated by Britton et al. (1977, 1978, 1979). The patient was placed supine on a couch with lead shielding over the shoulders, a gamma camera in the vertex position, and a probe detector over the aorta. After the positioning had

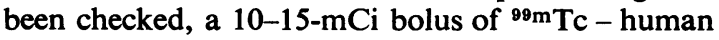
serum albumin (HSA) was injected into the right antecubital fossa and data recorded for the first 
pass through the cerebral vessels, and 3 min later at equilibrium. At this time, a blood sample was also taken for counting in a suitable phantom over the gamma camera. The data were recorded by a Varian $620 \mathrm{~L} 100$ computer so that time-activity curves could be generated from several regions of interest (ROIs) over the head. The data were processed by deconvolution analysis.

\section{Deconvolution method for cerebral flow}

Flow $(F)$ is calculated from the separate determination of volume (V) and mean transit time $(\mathfrak{t})$

$$
F=\frac{V}{i}
$$

The volume is obtained from the equilibrium count rate $(\mathrm{CE})$, and the blood sample count rate $(S$ $\mathrm{c} / \mathrm{sec} / \mathrm{ml}$ ) when the sample is counted in a suitable phantom over the gamma camera.

$$
V=\frac{C E}{S}
$$

However, by 3 minutes there has been some diffusion out of the circulation, and the volume as measured is the sum of the cerebral vascular volume and the extra-cerebral vascular volume. As the first pass study relates mainly to the intracerebral vessels, a correction factor (D) is obtained by comparing the first pass activity with the equilibrium activity,

$$
V=\frac{\text { CE.D }}{S}
$$

and this leads to an estimate of the intracerebral volume. The mean transit time is obtained by deconvolving the first pass cerebral curve $(C(t))$ against its input, the aortic first pass curve $(\mathrm{Ao}(\mathrm{t}))$ to obtain the retention function $(\mathrm{H}(\mathrm{t}))$ of the cerebral circulation for HSA.

$$
\mathrm{C}(\mathrm{t})=\mathrm{Ao}(\mathrm{t}) * \mathrm{H}(\mathrm{t})
$$

where ${ }^{*}$ represents the convolution integral. The mean transit time is then obtained from the retention function, either by an area/height method, or by a second deconvolution.

\section{Gamma variate method for cerebral flow}

The opportunity was taken to calculate cerebral flow by an alternative method and to compare the results with the standard technique. In this experimental approach a gamma variate curve was fitted to the data as a smoothing and extrapolating technique, referred to as ZGAMMA, the name of the computer programme. The volume was derived by combining equation $2 \mathrm{~A}$ with equation $4 \mathrm{~A}$ - the usual cardiac output formula.

$$
\begin{gathered}
C O=\frac{B V \cdot C E}{\int_{0}^{t} C(t) d t} \\
V=\frac{\int_{0}^{t} C(t) d t . C O}{S . B V}
\end{gathered}
$$

Where $\int_{0}^{t} C(t) d t$ is the area under the first pass curve, $\mathrm{BV}$ is the blood volume, and $\mathrm{CO}$ the cardiac output. It may be seen that the volume is proportional to the first pass area, as indicated by Nilsson, Rikner and Wolgast (1977). The ratio CO/BV may be determined from the pulmonary transit time (PTT) since, except for patients with cardiac dilatation, the pulmonary or cardiopulmonary blood volume is related to the total blood volume (Giuntini et al., 1963; Levinson, Pacifico and Frank, 1966). The PTT is calculated from the aortic probe curve which also contains components of the superior vena cava and pulmonary artery activities. The transit time index $(\mathfrak{t})$ is obtained by calculating the mean transit time for the aortic curve and subtracting it from that for the cerebral ROI curves. It is then corrected for the minimum cerebral transit time.

When using ZGAMMA the volume is obtained from first pass data and so relates only to the intracerebral vessels, thus needing no correction for extracerebral vessels. The time obtained is not a true mean transit time and so when using equation 1 , the value obtained should be regarded as an index of flow rather than a true blood flow. As such it is satisfactory for serial comparative studies. The main reason for developing this index was for it to be faster and simpler to calculate.

\section{Plan of study}

The study was designed to be 'double-blind' and to this end, Pfizer Ltd supplied 2 sets of tablets which were identical in appearance, labelled 'Drug $A$ ' and 'Drug B', and contained either prazosin $1.0 \mathrm{mg}$ or lactose $1 \mathrm{mg}$. In addition, there was a randomization table to indicate which drug should be taken first for each individual. Each individual had 2 CBF studies done, one with each drug, and wherever possible at the same time of day exactly one week apart. The measurement of CBF was designed to be made after about one hr after administration, at the time of high plasma prazosin levels (Verbersselt et al. 1976). The sequence of events for each CBF measurement was as follows: on arrival in the Department, the subject was allowed to rest for 5-10 min and then initial pulse rate and BP readings taken before being given either drug $A$ or drug B. In addition, each subject was given $400 \mathrm{mg}$ of potassium perchlorate which is a standard nuclear medicine technique to protect the thyroid gland against the uptake of ${ }^{99 \mathrm{~m} T c}$-pertechnetate. There was then a wait of approximately $45 \mathrm{~min}$ to allow 
the drugs to be absorbed, and then the subject was taken to the gamma camera and prepared for the $\mathrm{CBF}$ measurement. The preparations involved placing an indwelling cannula in a vein in the right antecubital fossa, placing the subject on a couch with lead shielding over the shoulders and positioning him in front of the gamma camera for a vertex view, placing a focused probe detector over the arch of the aorta, and ascertaining its position with one or more 'siting injections' of $1 \mathrm{mCi}$ of ${ }^{99 \mathrm{~m} T c}$ pertechnetate. This process took approximately $15 \mathrm{~min}$, and shortly before starting the measurement proper, readings were taken of the pulse rate, BP and carbon dioxide tension $\left(\mathrm{PCO}_{2}\right)$. Initially, the $\mathrm{PCO}_{2}$ was measured with an end-expiratory $\mathrm{CO}_{2}$ meter but, as some patients had difficulty maintaining a good seal with either mask or mouthpiece and the instrument proved unreliable, later measurements were done on venous blood taken from a warm resting arm.

The actual CBF measurement was done by injecting a bolus of $15 \mathrm{mCi}$ of ${ }^{99 \mathrm{~m} T c-H S A}$ and simultaneously recording data from the gamma camera into the computer, and from the aortic probe on to paper tape for later transfer to the computer. Immediately after this, repeat measurement of $\mathrm{PCO}_{2}$, pulse rate and BP were made and, in addition, a blood sample for determination of the packed cell volume (PCV) and prazosin levels. The subject then underwent measurements of pulse rates and BP before and after

TABLE 1. Results of a double-blind study to assess effect of a single 1-mg dose of prazosin on hypertensive patients

\begin{tabular}{|c|c|c|c|c|c|c|c|c|c|c|c|c|c|}
\hline \multirow[b]{2}{*}{ Patient } & \multirow[b]{2}{*}{$\begin{array}{c}\text { PCV } \\
\%\end{array}$} & \multirow[b]{2}{*}{$\begin{array}{c}\text { Drug } \\
(*)\end{array}$} & \multirow{2}{*}{$\begin{array}{c}\text { Prazosin } \\
\text { concen- } \\
\text { tration } \\
(\mathrm{ng} / \mathrm{ml})\end{array}$} & \multirow[b]{2}{*}{$\begin{array}{c}\text { BP } \\
(\mathrm{mmHg})\end{array}$} & \multirow{2}{*}{$\begin{array}{l}\text { Pulse } \\
\text { (beats/ } \\
\text { min) }\end{array}$} & \multirow[b]{2}{*}{$\underset{(\dagger)}{\mathrm{CO}_{2}}$} & \multicolumn{3}{|c|}{ DECONV } & \multicolumn{3}{|c|}{ ZGAMMA } & \multirow[b]{2}{*}{$\underset{(* *)}{\mathrm{CO} / \mathrm{BV}}$} \\
\hline & & & & & & & $\begin{array}{l}\text { Vol. } \\
\text { (ml) }\end{array}$ & $\begin{array}{l}\text { Time } \\
(\mathrm{sec})\end{array}$ & $\begin{array}{l}\text { Flow } \\
(\mathrm{ml} / \mathrm{min})\end{array}$ & $\begin{array}{l}\text { Vol. } \\
\text { (ml) }\end{array}$ & $\begin{array}{l}\text { Time } \\
(\mathrm{sec})\end{array}$ & $\begin{array}{l}\text { Flow } \\
(\mathrm{ml} / \mathrm{min})\end{array}$ & \\
\hline $\begin{array}{l}1 \\
1\end{array}$ & $\begin{array}{l}45 \\
46\end{array}$ & $\begin{array}{l}\text { AC } \\
\text { BC }\end{array}$ & & $\begin{array}{l}158 / 112 \\
205 / 127\end{array}$ & 74 & $\begin{array}{l}\text { E } 3 \cdot 7 \\
\text { E } 4.4\end{array}$ & $\begin{array}{l}96 \cdot 7 \\
90 \cdot 8\end{array}$ & $\begin{array}{l}6 \cdot 78 \\
7 \cdot 07\end{array}$ & $\begin{array}{l}855 \\
769\end{array}$ & $\begin{array}{l}87 \cdot 2 \\
73 \cdot 6\end{array}$ & $\begin{array}{l}7 \cdot 70 \\
5 \cdot 95\end{array}$ & $\begin{array}{l}679 \\
769\end{array}$ & $\begin{array}{l}1 \cdot 10 \\
1 \cdot 14\end{array}$ \\
\hline $\begin{array}{l}2 \\
2\end{array}$ & $\begin{array}{l}43 \\
43\end{array}$ & $\begin{array}{l}\text { A } \\
\text { B }\end{array}$ & $\begin{array}{c}2 \cdot 26 \\
0\end{array}$ & $\begin{array}{l}130 / 83 \\
140 / 87\end{array}$ & & $\begin{array}{l}\text { E } 5 \cdot 1 \\
\text { E } 5 \cdot 7\end{array}$ & \multicolumn{3}{|c|}{ Not available } & $\begin{array}{l}105 \cdot 2 \\
100 \cdot 5\end{array}$ & $\begin{array}{l}5 \cdot 93 \\
5 \cdot 72\end{array}$ & $\begin{array}{l}1064 \\
1054\end{array}$ & $\begin{array}{l}1.29 \\
1.06\end{array}$ \\
\hline $\begin{array}{l}3 \\
3\end{array}$ & $\begin{array}{l}50 \\
48\end{array}$ & $\begin{array}{l}\text { B } \\
\text { A }\end{array}$ & $\begin{array}{r}5 \cdot 4 \\
0\end{array}$ & $\begin{array}{l}200 / 105 \\
160 / 100\end{array}$ & & $\begin{array}{l}\text { E } 3.7 \\
\text { E } 3.2\end{array}$ & \multicolumn{3}{|c|}{ Not available } & $\begin{array}{r}82 \cdot 9 \\
104 \cdot 7\end{array}$ & $\begin{array}{l}5 \cdot 69 \\
5 \cdot 62\end{array}$ & $\begin{array}{r}874 \\
1117\end{array}$ & $\begin{array}{l}0 \cdot 98 \\
1 \cdot 12\end{array}$ \\
\hline $\begin{array}{l}4 \\
4\end{array}$ & $\begin{array}{l}40 \\
42\end{array}$ & $\begin{array}{l}\text { AD } \\
\text { BD }\end{array}$ & $\begin{array}{r}2 \cdot 5 \\
0\end{array}$ & $\begin{array}{l}190 / 130 \\
215 / 132\end{array}$ & $\begin{array}{l}68 \\
64\end{array}$ & $\begin{array}{l}\text { E } 4 \cdot 1 \\
\text { E } 5 \cdot 4\end{array}$ & $\begin{array}{r}105 \cdot 5 \\
85 \cdot 7\end{array}$ & $\begin{array}{l}5 \cdot 65 \\
4 \cdot 96\end{array}$ & $\begin{array}{l}1120 \\
1037\end{array}$ & $\begin{array}{l}82 \cdot 2 \\
76 \cdot 4\end{array}$ & $\begin{array}{l}6 \cdot 18 \\
6 \cdot 26\end{array}$ & $\begin{array}{l}798 \\
732\end{array}$ & $\begin{array}{l}1 \cdot 10 \\
0 \cdot 88\end{array}$ \\
\hline $\begin{array}{l}5 \\
5\end{array}$ & $\begin{array}{l}43 \\
42\end{array}$ & $\begin{array}{l}\text { A } \\
\text { B }\end{array}$ & $\begin{array}{r}2 \cdot 8 \\
0\end{array}$ & $\begin{array}{l}137 / 90 \\
137 / 97\end{array}$ & $\begin{array}{l}51 \\
50\end{array}$ & $\begin{array}{l}\text { E } 4 \cdot 4 \\
\text { E } 2 \cdot 3\end{array}$ & $\begin{array}{l}104 \cdot 8 \\
116 \cdot 3\end{array}$ & $\begin{array}{l}6 \cdot 22 \\
6 \cdot 17\end{array}$ & $\begin{array}{l}1009 \\
1131\end{array}$ & $\begin{array}{l}105 \cdot 0 \\
107 \cdot 0\end{array}$ & $\begin{array}{l}8 \cdot 29 \\
8 \cdot 20\end{array}$ & $\begin{array}{l}769 \\
782\end{array}$ & $\begin{array}{l}1.00 \\
1.00\end{array}$ \\
\hline $\begin{array}{l}6 \\
6\end{array}$ & $\begin{array}{l}43 \\
53\end{array}$ & $\begin{array}{l}\mathrm{BC} \\
\mathrm{AC}\end{array}$ & $\begin{array}{r}0 \\
4 \cdot 8\end{array}$ & $\begin{array}{l}175 / 115 \\
137 / 87\end{array}$ & $\begin{array}{l}60 \\
64\end{array}$ & $\begin{array}{l}\text { V } 7 \cdot 7 \\
\text { V } 6.4\end{array}$ & $\begin{array}{l}64 \cdot 2 \\
64 \cdot 5\end{array}$ & $\begin{array}{l}6 \cdot 12 \\
6 \cdot 10\end{array}$ & $\begin{array}{l}630 \\
635\end{array}$ & $\begin{array}{l}58 \cdot 3 \\
76 \cdot 9\end{array}$ & $\begin{array}{l}5 \cdot 50 \\
4 \cdot 61\end{array}$ & $\begin{array}{r}636 \\
1000\end{array}$ & $\begin{array}{l}1 \cdot 02 \\
1 \cdot 11\end{array}$ \\
\hline $\begin{array}{l}7 \\
7\end{array}$ & $\begin{array}{l}43 \\
43\end{array}$ & $\begin{array}{l}\text { A } \\
\text { B }\end{array}$ & $\begin{array}{r}7 \cdot 5 \\
0\end{array}$ & $\begin{array}{l}190 / 125 \\
205 / 130\end{array}$ & $\begin{array}{l}74 \\
74\end{array}$ & $\begin{array}{l}\text { E } 3.9 \\
\text { V } 6.1\end{array}$ & $\begin{array}{r}113 \cdot 1 \\
94 \cdot 7\end{array}$ & $\begin{array}{l}8 \cdot 19 \\
8 \cdot 26\end{array}$ & $\begin{array}{l}825 \\
688\end{array}$ & $\begin{array}{l}138 \cdot 7 \\
114 \cdot 1\end{array}$ & $\begin{array}{l}8 \cdot 75 \\
9 \cdot 23\end{array}$ & $\begin{array}{l}952 \\
742\end{array}$ & $\begin{array}{l}1.09 \\
0.87\end{array}$ \\
\hline $\begin{array}{l}8 \\
8\end{array}$ & $\begin{array}{l}44 \\
41\end{array}$ & $\begin{array}{l}\text { A } \\
\text { B }\end{array}$ & $\begin{array}{r}2 \cdot 9 \\
0\end{array}$ & $\begin{array}{l}152 / 97 \\
147 / 100\end{array}$ & $\begin{array}{l}56 \\
60\end{array}$ & $\begin{array}{l}\text { E } 3.6 \\
\text { V } 6.4\end{array}$ & $\begin{array}{r}109 \cdot 7 \\
81 \cdot 1\end{array}$ & $\begin{array}{l}7 \cdot 80 \\
7 \cdot 92\end{array}$ & $\begin{array}{l}844 \\
614\end{array}$ & $\begin{array}{r}101 \cdot 7 \\
82 \cdot 3\end{array}$ & $\begin{array}{l}7 \cdot 08 \\
8 \cdot 90\end{array}$ & $\begin{array}{l}862 \\
555\end{array}$ & $\begin{array}{l}0.83 \\
0.66\end{array}$ \\
\hline $\begin{array}{l}9 \\
9\end{array}$ & & $\begin{array}{l}\text { B } \\
\text { A }\end{array}$ & $\begin{array}{r}0 \\
6 \cdot 0\end{array}$ & $\begin{array}{l}150 / 100 \\
145 / 100\end{array}$ & $\begin{array}{l}84 \\
86\end{array}$ & V 6.5 & $\begin{array}{r}103 \cdot 3 \\
99 \cdot 6\end{array}$ & $\begin{array}{l}6 \cdot 93 \\
5 \cdot 40\end{array}$ & $\begin{array}{r}894 \\
1108\end{array}$ & $\begin{array}{l}107 \cdot 2 \\
116 \cdot 2\end{array}$ & $\begin{array}{l}6 \cdot 65 \\
6 \cdot 44\end{array}$ & $\begin{array}{r}967 \\
1083\end{array}$ & $\begin{array}{l}1 \cdot 27 \\
1 \cdot 15\end{array}$ \\
\hline $\begin{array}{l}10 \\
10\end{array}$ & $\begin{array}{l}43 \\
41\end{array}$ & $\begin{array}{l}\text { B } \\
\text { A }\end{array}$ & $\begin{array}{r}0 \\
5 \cdot 7\end{array}$ & $\begin{array}{l}155 / 105 \\
135 / 87\end{array}$ & $\begin{array}{l}74 \\
75\end{array}$ & $\begin{array}{l}\text { V } 6.5 \\
\text { V } 6 \cdot 3\end{array}$ & $\begin{array}{l}87 \cdot 4 \\
90 \cdot 0\end{array}$ & $\begin{array}{l}6 \cdot 64 \\
6 \cdot 60\end{array}$ & $\begin{array}{l}790 \\
818\end{array}$ & $\begin{array}{r}98 \cdot 1 \\
116 \cdot 0\end{array}$ & $\begin{array}{l}6 \cdot 87 \\
6 \cdot 74\end{array}$ & $\begin{array}{r}857 \\
1033\end{array}$ & $\begin{array}{l}1 \cdot 10 \\
1 \cdot 39\end{array}$ \\
\hline $\begin{array}{l}11 \\
11\end{array}$ & $\begin{array}{l}44 \\
42\end{array}$ & $\begin{array}{l}\text { B } \\
\text { A }\end{array}$ & $\begin{array}{r}0 \\
3 \cdot 8\end{array}$ & $\begin{array}{l}130 / 80 \\
122 / 77\end{array}$ & $\begin{array}{l}84 \\
70\end{array}$ & $\begin{array}{l}\text { E } 4 \cdot 3 \\
\text { E } 5 \cdot 0\end{array}$ & \multicolumn{3}{|c|}{ Not available } & $99 \cdot 1^{N}$ & $\begin{array}{l}\text { availa } \\
5 \cdot 73\end{array}$ & ${ }_{1038}$ & $\begin{array}{l}1.09 \\
1.21\end{array}$ \\
\hline $\begin{array}{l}12 \\
12\end{array}$ & 39 & $\begin{array}{l}\text { B } \\
\text { A }\end{array}$ & $\begin{array}{r}0 \\
6 \cdot 2\end{array}$ & $\begin{array}{l}120 / 80 \\
140 / 77\end{array}$ & $\begin{array}{l}62 \\
74\end{array}$ & $\begin{array}{l}\text { E } 3.6 \\
\text { E } 4.0\end{array}$ & $\begin{array}{l}68 \cdot 1 \\
76 \cdot 6\end{array}$ & $\begin{array}{l}5 \cdot 38 \\
4 \cdot 65\end{array}$ & $\begin{array}{l}759 \\
989\end{array}$ & $\begin{array}{l}90 \cdot 5 \\
81 \cdot 1\end{array}$ & $\begin{array}{l}7 \cdot 28 \\
5 \cdot 29\end{array}$ & $\begin{array}{l}746 \\
919\end{array}$ & $\begin{array}{l}1.06 \\
1.78\end{array}$ \\
\hline $\begin{array}{l}13 \\
13\end{array}$ & $\begin{array}{l}42 \\
45\end{array}$ & $\begin{array}{l}\text { A } \\
\text { B }\end{array}$ & $\begin{array}{r}3 \cdot 4 \\
0\end{array}$ & $\begin{array}{l}120 / 90 \\
120 / 100\end{array}$ & & $\begin{array}{l}\text { V } 4 \cdot 7 \\
\text { V } 5 \cdot 0\end{array}$ & $\begin{array}{l}110 \cdot 0 \\
100 \cdot 9\end{array}$ & $\begin{array}{l}5 \cdot 70 \\
6 \cdot 42\end{array}$ & $\begin{array}{r}1159 \\
944\end{array}$ & $\begin{array}{r}82 \cdot 0 \\
103 \cdot 1\end{array}$ & $\begin{array}{l}6 \cdot 10 \\
6 \cdot 36\end{array}$ & $\begin{array}{l}807 \\
968\end{array}$ & $\begin{array}{l}0.93 \\
1 \cdot 19\end{array}$ \\
\hline
\end{tabular}

(*) A, Prazosin; B, Placebo; C, Slow release oxprenolol $160 \mathrm{mg}$ daily; D, Atenolol $200 \mathrm{mg}$ daily.

(**) CO, Cardiac output $\}$ (in units of reciprocal min.)

( $\dagger$ E, End-expiratory air $(\%$ of $)$; V, Pressure in peripheral venous blood ( $\mathrm{kPa})$. 
TABLE 2. Study of the effect of prazosin on cerebral blood flow

\begin{tabular}{|c|c|c|c|c|c|c|c|c|c|}
\hline & \multirow{2}{*}{$\begin{array}{c}\text { Blood } \\
\text { pressure } \\
(\mathrm{mmHg})\end{array}$} & \multirow{2}{*}{$\begin{array}{l}\text { Pulse } \\
\text { (beats } \\
\text { /min) }\end{array}$} & \multicolumn{3}{|c|}{ DECONV. } & \multicolumn{3}{|c|}{ ZGAMMA } & \multirow{2}{*}{$\mathrm{CO} / \mathrm{BV}$} \\
\hline & & & $\begin{array}{l}\text { Vol. } \\
\text { (ml) }\end{array}$ & $\begin{array}{l}\text { Time } \\
(\mathrm{sec})\end{array}$ & $\begin{array}{c}\text { Flow } \\
(\mathrm{ml} / \mathrm{min})\end{array}$ & $\begin{array}{l}\text { Vol. } \\
(\mathrm{ml})\end{array}$ & $\begin{array}{l}\text { Time } \\
(\mathrm{sec})\end{array}$ & $\begin{array}{c}\text { Flow } \\
(\mathrm{ml} / \mathrm{min})\end{array}$ & \\
\hline $\begin{array}{l}\text { No. of patients } \\
\text { Mean prazosin } \\
\text { Mean placebo }\end{array}$ & $\begin{array}{c}13 \\
147 / 97 \\
161 / 104\end{array}$ & $\begin{array}{r}9 \\
69 \\
68\end{array}$ & $\begin{array}{l}10 \\
97 \\
89\end{array}$ & $\begin{array}{l}10 \\
6.31 \\
6.59\end{array}$ & $\begin{array}{r}10 \\
936 \\
821\end{array}$ & $\begin{array}{l}11 \\
99 \\
92\end{array}$ & $\begin{array}{l}12 \\
6 \cdot 56 \\
6 \cdot 88\end{array}$ & $\begin{array}{r}11 \\
909 \\
792\end{array}$ & $\begin{array}{l}13 \\
1 \cdot 16 \\
1 \cdot 02\end{array}$ \\
\hline $\begin{array}{l}\text { Mean difference } \\
\text { S.E. difference } \\
\text { Difference as } \% \text { of } \\
\text { placebo }\end{array}$ & $\begin{array}{l}-14 /-7^{* *} \\
6 \cdot 12 / 2 \cdot 32 \\
-8 \cdot 7 /-6 \cdot 9\end{array}$ & $\begin{array}{l}0.63 \\
2 \cdot 82\end{array}$ & $\begin{array}{l}7 \\
4.05\end{array}$ & $\begin{array}{r}-0.33 \\
0.20\end{array}$ & $\begin{array}{l}116^{*} \\
44.9\end{array}$ & $\begin{array}{l}8 \\
4 \cdot 83\end{array}$ & $\begin{array}{r}-0.37 \\
0.31\end{array}$ & $\begin{array}{l}117^{*} \\
44 \cdot 45\end{array}$ & $\begin{array}{l}0.15 \\
0.07\end{array}$ \\
\hline
\end{tabular}

*, Significant at $5 \%$ level but not at $1 \%$ level; **, Significant at $1 \%$ level; CO/BV, Cardiac output/blood volume ratio.

supervised exercise - running up and down 2 flights of stairs. This was to bring out any first dose effect. Side effects were elicited by asking the patients how they felt and all comments were recorded.

\section{Results}

Data analysed according to both the deconvolution method (DECONV) and the gamma variate fitting method (zGAMMA) outlined earlier in this paper. Sequential analysis was applied to the CBF values. Results from the 13 individuals are presented in Table 1, with each individual's results presented in the order in which they were obtained. It should be noted that the BPs in Table 1 are not those used to determine admission to the study, but those recorded one hour after administration of drug $A$ or B. The results were analysed using 2 methods$\mathrm{PCV}, \mathrm{CO}_{2}$ tension, $\mathrm{BP}, \mathrm{CO} / \mathrm{BV}$ by the Wilcoxon method; measurements of flow, time and volume by Student's $t$ test.

Neither PCV nor $\mathrm{CO}_{2}$ showed any significant difference between samples taken when drug $A$ was used and those taken when drug $B$ was used. The $\mathrm{CO} / \mathrm{BV}$ was analysed for differences either between drug A or drug B (Table 2), with prazosin showing a mean increase of $15 \%$ for ratio of $\mathrm{CO} / \mathrm{BV}$. BP measurements showed a significant reduction of both systolic and diastolic levels at the $5 \%$ and $1 \%$ levels respectively when prazosin was taken (Table 2).The prazosin concentrations obtained are in the range inducing lowering of BP (Bateman et al., 1980).

Cerebral flow, volume and transit time were analysed in several groups, namely: according to which analysis method was used (ZGAMMA or DECONV), first or second measurements, and drug A or drug B. There was no significant difference between values obtained by the 2 methods of analysis, summarized in Table 3 , nor between values obtained by first or second studies. The zGAMMA method showed that when prazosin was used there was an $8 \%$ increase in the group mean volume and a
$5 \%$ decrease in mean transit time giving an increase in mean flow of $16 \%(P<0.05)$.

The deconvolution method showed that a $7 \%$ increase in volume and a $3 \%$ decrease in mean transit time followed the use of prazosin. This gave a $14 \%$ increase in cerebral flow, just significant at the $5 \%$ level, in those taking prazosin (Table 2). A reproducibility study previously undertaken in 10 persons as part of a validation programme showed an insignificant $3 \%$ difference in repeated cerebral flow measurements.

TABLE 3. Comparison of DECONV. and ZGAMMA measurements

\begin{tabular}{lccl}
\hline & Volume & Time & Flow \\
\hline Group A & & & \\
$\quad n$ & 12 & 12 & 12 \\
Mean of difference & -3.56 & -0.44 & 36.83 \\
$\quad$ Standard error & 5.79 & 0.31 & 61.90 \\
& & & \\
Group B & 11 & 11 & 11 \\
$\quad n$ & -1.35 & -0.53 & 58.18 \\
$\quad$ Mean of difference & 3.70 & 0.30 & 44.06 \\
$\quad$ Standard error & &
\end{tabular}

Group A - measurements on patients after prazosin treatment.

Group B - measurements on patients after placebo treatment.

\section{Discussion}

There was a significant reduction in both systolic and diastolic BP for individuals on drug A (prazosin). As prazosin was being given at the relatively low dose of $1.0 \mathrm{mg}$ and the number of individuals in the study was small (13), this was an indication of the efficacy of prazosin.

The results of both the DECONV and ZGAMMA methods show a slight, just statistically significant, increase in $\mathrm{CBF}$ in the prazosin group. Using the ZGAMMA method, the fraction $\mathrm{CO} / \mathrm{BV}$, calculated from the PTT, assumed that the ratio of pulmonary blood volume to total blood volume remained 
constant: Falch et al. (1979) have recently produced evidence that with prazosin an increase in systemic volume occurs without change in pulmonary blood volume supporting this assumption. These results virtually exclude a fall of $\mathrm{CBF}$ on prazosin. This finding may be interpreted as suggesting that the first dose effect of prazosin is likely to be due to excessive hypotension in some individuals rather than the extreme end of a spectrum of reduced CBF. The preservation of CBF during a therapeutically useful fall in BP may indicate a place for prazosin in hypertensive patients with cerebrovascular disorder.

\section{Acknowledgments}

We thank the St Bartholomew's joint research body for support for M.D.R., the Wellcome Trust for support for M.G., and Pfizer Ltd for their help and formulation of the tablets for the double-blind study.

\section{References}

Bateman, D. N., Hobbs, D. C., Twomey, T. W. \& Rawlins, M. D. (1980) Prazosin, pharmacokinetics and concentration effect studies in normal volunteers. In: Prazosin Symposium, London, Royal Society of Medicine (in press).

Bendall, M. J., Balock, K. H. \& Wilson, P. R. (1975) Side-effects due to the treatment of hypertension with prazosin. British Medical Journal, 2, 727.

Britton, K. E., Granowska, M., Rutland, M., Lee, T. Y., Nimmon, C. C., Petrosino, I. \& Lumley, J. S. P. (1979) Non-invasive measurement of regional cerebral flow before and after microvascular surgery. In: Progress in Stroke Research I (Ed by Greenhalgh, R. M. \& Rose, F. S.), p. 307. Pitman, London.
Britton, K. E., Nimmon, C. C., Lee, T. Y., Jarritt, P. H. Granowska, M. \& McAlister, J. M. (1977) Cerebrovascular disorder: Assessment with radionuclides. In: Advanced Medicine Vol. 13, p. 444. Pitman, London.

Britton, K. E., Nimmon, C. C., Lee, T. Y., Jarritt, P. H, Granowska, M., Greening, A. \& McAlister, J. M. (1978) Carotid and cerebral flow. In: Information Processing in Medical Imaging (Ed by Brill, A. B., Price, R. R., McLain, W. J. \& Landay, M. W.), p. 499. Oakridge National Laboratory, U.S.A.

Falch, D. K., Quist Paulsen, A., OdegaARd, A. E. \& Norman, N. (1979) Central and renal circulation, renin and alosterone in plasma during prazosin treatment in essential hypertension. Acta medica scandinavica, 114, 1.

Gabriel, R., Meek, D. \& Grosh, B. C. (1975) Collapse after prazosin hydrochloride. Lancet, i, 1095.

Giuntini, C., Lewis, M. L., Salesluis, A. \& Harvey, R. M. (1963) A study of the pulmonary blood volume in man by quantitative radiocardiography. Journal of Clinical Investigation, 42, 1589.

Graham, R. M., Thornell, I. R., Gain, J. M., Bognoli, C., OAtes, H. F. \& Stokes, G. F. (1976) Prazosin: the firstdose phenomenon. British Medical Journal, 1, 1293.

Levinson, G. E., Pacifico, A. D. \& Frank, M. J. (1966) Measurement of total cardiopulmonary blood volume in normal human subjects at rest and during exercise. Circulation, 33, 347.

Nilsson, B. W., Rikner, G. \& Wolgast, M. (1977) On the theory of an intravenous isotope method of cerebral blood flow measurements Scandinavian Journal of Clinical Laboratory Investigation, 37, 195.

Turner, A. S., Watson, O. F. \& Brocklehurst, J. E. (1977) Prazosin in hypertension. Medical Journal of Australia (Specialists' Suppl.) 2, 33.

Verbesselt, R., Mullie, A., Tuandramaga, T. B., De SChepper, P. J. \& Dersain, P. (1976) The effect of food intake as the plasma kinetics and toleration of prazosin. Acta therapeutica, 2, 27. 